\section{UM LIVRO FUNDAMENTAL PARA TODO ANALISTA EM FORMAÇÃO}

\section{Fundamentos da psicanálise de Freud a Lacan, a clínica da fantasia, v.2, de Marco Antonio Coutinho Jorge. Rio de Janeiro: Jorge Zahar, 2010. 288p.}

\footnotetext{
Vanisa Maria da Gama Moret Santos

Psicanalista, autora de Fragmentos (2003) e As faces do tempo (2008), mestre em psicanálise (Uerj), especialista em psicologia clínica (PUC-Rio), especialista em língua inglesa (Uerj), membro dos Fóruns do Campo Lacaniano do Rio de Janeiro.
}

Lançado em 2010, o segundo volume, Fundamentos da psicanálise de Freud a Lacan, a clínica da fantasia, de Marco Antonio Coutinho Jorge, pertence à série dedicada à revisão de tópicos importantes das obras de Freud e Lacan não foge ao estilo rigoroso de Jorge, mas inclui de modo original, arte, literatura, música e cultura, o que torna sua leitura extremamente agradável. Além disso, fica claro para o leitor que Jorge é um homem de seu tempo, refletindo sobre assuntos atuais como a homofobia e os fatos que mais marcaram o século XXI, como os ataques terroristas às Torres Gêmeas nos Estados Unidos em 11 de setembro de 2001

O tema da fantasia é tratado através de preciosos recortes de textos na obra de Freud e no ensino de Lacan. Na parte I, ele aborda o tema da fantasia e da pulsão sexual. Tratando a pulsão sexual como a primeira subversão freudiana, Jorge chama a atenção do leitor, por exemplo, para palavra 'civilizada', empregada por Freud em seu artigo "Moral sexual 'civilizada' e doença nervosa” (FREUD, 1908/1996). Em tom provocativo, insinua que “[...] podemos supor que elas são utilizadas para designar um uso figurativo do termo 'civilizado', no sentido mesmo de questionar o que é civilizado ou não" (JORGE, M.A.C. /2010:25). No item 2 dessa primeira parte, Jorge discorre sobre o que nomeou de "O ciclo da fantasia". Ineditamente assim referido por Jorge, tal ciclo é delineado no tempo (de 1906 a 1911) para mostrar que foi nesse período que Freud construiu os trabalhos mais importantes sobre a fantasia inconsciente, como $A$ Gradiva de Jensen (FREUD, 1907/1996), O poeta e o fantasiar (1908), Fantasias histéricas e sua relação com a bissexualidade (FREUD, 1908/1996), dentre outros. Recorrendo a grafos originais e extremamente elucidativos, consegue dar uma verdadeira aula sobre o assunto.

"Fantasia e pulsão de morte" é o tema da parte II do livro e evidencia a relação entre pulsão de morte e fantasia. Relação essa que se dá pelo viés do desejo que traz um parentesco pouco explícito e longínquo com a Coisa. Mas como Jorge salienta, a fantasia constitui o passo fundador do sujeito justamente porque, nesse caso, o sujeito não está mais ligado à Coisa, mas ao objeto causa de desejo.

Retomando a definição de inconsciente dada por Freud a Georg Groddeck e a comparando à definição que aquele 
daria para a pulsão tempos depois, Jorge dirá que: "O inconsciente é exatamente o verdadeiro intermediário entre o somático e o psíquico. Talvez, o missing link, o elo perdido, tão procurado" (JORGE, M.A.C. /2010: 117). Mas enfatiza que "Devemos, pois, tomar essa aparente troca conceitual como uma chave para a compreensão do que é inconsciente e pulsão" (idem). Embora sejam conceitos diferentes, há algo que parece ligá-los, como nos esclarece um pouco mais à frente. É justamente isso que essa parte do trabalho tentará elucidar fazendo uma verdadeira retomada do tema em Freud e Lacan.

Partindo do ano em que Freud lança o conceito de pulsão, em 1905, passando pelo primeiro dualismo pulsional em 1910, chegará finalmente à segunda tópica, com a noção de um segundo dualismo pulsional introduzido por Freud no "Mais além do princípio do prazer" (FREUD, 1920/1996). Mas acrescentará a isso à observação de Lacan, no Seminário 11 (LACAN, 1964/1998) de que toda pulsão é mesmo pulsão de morte. Quanto a isso, Jorge esclarecerá que o próprio Freud já o havia afirmado na parte VII do "Mais além do princípio do prazer".

Na página 150, a poesia de Florbela Espanca nos diz algo a mais sobre o luto impossível na melancolia. Sua poesia corrobora com a ideia de que, por não encontrar recursos internos para erotizar a pulsão de morte e por não ter condições subjetivas de fazer o trabalho de luto, o sujeito melancólico sucumbe drasticamente à perda do objeto.

Outro momento iluminador do trabalho de Marco Antonio sobre a pulsão de morte encontra-se no trecho em que ele correlaciona dois filmes muito tocantes: $\mathrm{O}$ declínio do império americano (1986) e As invasões bárbaras (2003). No primeiro, relaciona a pulsão sexual à eterna busca da satisfação em um cenário que exibe a liberação sexual dos anos 80 associada ao temor da AIDS. No segundo, o que vemos é o desenrolar do tema da pulsão culminar em sua polaridade mortífera, pois a trama do filme tem início com o atentado às Torres Gêmeas em Nova York em 11 de setembro. Através de sua lente, vemos que há um desdobramento implícito de O declínio para As invasões correlato ao deslizamento da pulsão sexual para a pulsão de morte.

Como vemos, a construção desse segundo volume é fruto de um cuidadoso trabalho que se deu como uma tentativa constante e bem-sucedida de iluminar a teoria com o que há de melhor em arte e através de acontecimentos importantes em nossa cultura. Sobre esse assunto - o da iluminação - temos a parte III, cujo tema é o "Despertar". Jorge recorrerá mais uma vez à literatura citando, por exemplo, trechos de $A$ paixão segundo G.H. Há um recorte em especial no qual ele tenta fazer claro aquilo que é experimentado no final de uma análise, ou seja, a destituição subjetiva. Aliás, é G.H. que ilustra isso muito bem, "Por um átimo experimentei a vivificadora morte”. Nesse instante de concluir, o sujeito em final de análise experimenta o que o poeta sente toda vez em que se depara com o objeto de sua criação: não é mais ele quem está ali, mas tão somente o texto.

Marco Antonio Coutinho Jorge nos convida, portanto, a refletir e a reafirmar nosso desejo em relação à clínica e à transmissão da psicanálise sem perder de vista a arte e a poesia.

Recebido em 2/4/2012.

Aprovado em 14/5/2012.

Vanisa Maria da Gama Moret Santos vanisasantos@ig.com.br 